\title{
Głos w dyskusji o zaniechaniu ścigania jako sposobie reakcji na przestępstwo w prawnie dopuszczalnym procesie karnym
}

\begin{abstract}
The subject of considerations is an attempt to describe and assess the institution of cessation of prosecution, resulting from reaching an agreement, as reaction to crime. The effective consensus-driven approach ought to be aimed at combining court instruments and values with the axiological basis of agreement-based litigation (namely, principle of restorative justice), and also with legal measures which allow to mete out a due penal reaction or, frequently, the cessation of prosecution. In case of proceedings regarding misdemeanours, where there is a possibility of eliminating the consequences of the crime solely by compensatory actions within victim-perpetrator relation, the state ought to waive the execution of ius puniendi. What should constitute the limit of waiving the right to punish is a combination of circumstances such as: negligible degree of social harm, reaching a plea agreement that includes the manner of compensation, along with executing thereof. Then, the sufficient reaction to crime is redressing damage or compensation for the harm suffered and the prosecutor's decision to cease prosecution. The stage of judicial proceeding does not have to and should not be merely a forum for reaching and executing court agreements. The described variant of cessation of the prosecution combines instrumental values, such as the promptness and cost-effectiveness of proceedings with non-instrumental ones, such as due process and implementation of restorative justice. Through only partial waiver of the trial subject implementation, cessation of the proceedings may constitute a compromise between legalistic values and those of judicial opportunism.
\end{abstract}

Keywords: cessation of the prosecution resulting from reaching court agreement, judicial opportunism, conciliation, consensus-driven approach, preparatory proceedings, restorative justice, the discretionary power of prosecutors 


\section{Zaniechanie ścigania jako sposób reakcji na przestępstwo w prawnie dopuszczalnym procesie}

Przyczyny zaniechania ścigania $\mathrm{w}$ procesie karnym tradycyjnie wiążą się z wystąpieniem negatywnej przesłanki procesowej. Mowa o zdarzeniach procesowych, które skutkują koniecznością umorzenia postępowania bądź wydania postanowienia o odmowie jego wszczęcia ze względu na niedopuszczalność procesu. Należy odróżnić przyczyny zaniechania ścigania związane z prawną niedopuszczalnością ścigania od tych, które są związane z niecelowością. Wśród instytucji pozwalających na zaniechanie ścigania sprawcy przestępstwa, znanych polskiemu i zagranicznym systemom prawnym (a także wśród tych instytucji, które są możliwe do wyobrażenia) można wyróżnić dwie grupy instrumentów - instytucje pozwalające na zaniechanie ścigania ze względu na jego prawną lub faktyczną niecelowość. Niecelowość faktyczna związana jest najczęściej z brakiem praktycznych możliwości pociągnięcia sprawcy do odpowiedzialności (zbliżający się termin przedawnienia karalności czynu, brak faktycznej możliwości wykonania kary) i pozostaje poza polem rozważań - przykładem takiej instytucji w systemie prawa polskiego jest umorzenie rejestrowe (art. $325 \mathrm{f} \S 1$ k.p.k.) ${ }^{1}$. Wpływ tego przepisu na wzrost umorzeń postępowań karnych po przeprowadzeniu czynności $\mathrm{w}$ niezbędnym zakresie nie budzi wątpliwości. Z kolei spośród instytucji, które pozwalają na zaprzestanie ścigania z przyczyn stricte prawnych, można wyróżnić te, które znajdują zakorzenienie w oportunizmie (umorzenie absorpcyjne - art. $11 \S 1$ k.p.k.) oraz te, których źródło tkwi w przekonaniu o niezasadności ścigania z punktu widzenia celów postępowania. Takie przekonanie jest $\mathrm{z}$ reguły związane $\mathrm{z}$ określonymi zdarzeniami, które miały miejsce po popełnieniu czynu, a przed zapadnięciem decyzji procesowej (naprawienie szkody, zadośćuczynienie za doznaną krzywdę, pojednanie się pokrzywdzonego i sprawcy, pozytywny przebieg mediacji). Przekonanie o niecelowości ścigania może być też podyktowane samoistnym wyobrażeniem organu procesowego o bezzasadności prowadzenia postępowania ze względu na bagatelność sprawy lub brak społecznie doniosłych skutków przestępstwa. Większość tego rodzaju wypadków w prawie polskim to czyny o znikomym stopniu społecznej szkodliwości. Ich ściganie jest zatem nie tyle niecelowe, co niedopuszczalne. Jednak między czynem o znikomym stopniu społecznej szkodliwości a czynem,

${ }^{1} \mathrm{~W}$ ocenie J. Kurdelka u podstaw powołanej instytucji leży przekonanie Policji o tym, że perspektywa wykrycia sprawców już we wstępnej fazie postępowania jest minimalna, a w zasadzie - wystąpi brak punktu zaczepienia, który pozwalałby podejmować działania procesowe dla ustalenia i wykrycia sprawcy - tak: J. KuRDELEK: Umorzenie „rejestrowe" dochodzenia - uwagi praktyczne. Prok. i Pr. 2011, nr 3, Legalis. 
którego ściganie jest niecelowe, istnieje pewne pole „niczyje” - przy czym prawo polskie nie daje organom ścigania instrumentów „negatywnej” reakcji na takie zachowania. Sam podział możliwości oceny celowości ścigania na ściganie niedopuszczalne (art. 17 § 1 pkt 3 k.p.k.) i niecelowe (inne wypadki w prawnie dopuszczalnym procesie) jest skutkiem obowiązywania w polskim systemie prawnym zasady legalizmu. W systemach oportunistycznych, w tym we Francji, niecelowości ścigania nie podniesiono do rangi przesłanki procesowej, zatem w każdej sprawie, w której prokurator poweźmie informacje o popełnieniu przestępstwa samodzielnie podejmuje decyzję o tym, czy wszcząc postępowanie, zastosować alternatywne środki reakcji, czy wreszcie zaniechać ścigania bezwarunkowo ${ }^{2}$.

Niecelowość ścigania nie zawsze jest warunkowana czynnikiem stricte ekonomicznym. Nierzadko przemawia za nią przekonanie o bezzasadności realizacji ius puniendi wobec zrealizowania celów postępowania i zadośćuczynienia sprawiedliwości karnomaterialnej, jak i procesowej ze względu na zdarzenia, które miały miejsce już po popełnieniu czynu zabronionego. Powyższą myśl potwierdza wyrażony przez T. Schefflera pogląd na naturę „prawa karania”. Współczesne prawo karne, i to zarówno materialne, jak i procesowe, zakłada, że pełną ochroną ze strony państwa objęte są tylko te czyny, które władza publiczna ze względu na skutki materialne lub osobnicze uznaje za godne uwagi z punktu widzenia przede wszystkim jej interesów ${ }^{3}$. Dlatego u podstaw instytucji polegających na zaniechaniu ścigania $\mathrm{z}$ uwagi na zawarcie porozumienia przez strony postępowania przygotowawczego leży konglomerat okoliczności polegających na realizacji celów postępowania mimo jego nieprzeprowadzenia i braku celowości w realizacji sankcji państwowej. Nie budzi wątpliwości, że pierwsza z okoliczności warunkuje byt drugiej. Przedmiotem artykułu będzie refleksja nad instytucją polegającą na zaniechaniu ścigania (mimo jego prawnej dopuszczalności) wobec podjęcia przez sprawcę i pokrzywdzonego działań konsensualno-kompensacyjnych, które kształtują przekonanie o bezzasadności realizacji sankcji państwowej. Mając świadomość wieloznaczności pojęcia „zaniechanie ścigania", będę posługiwał się nim w celu opisu instytucji będącej przedmiotem refleksji. Inne rodzaje zaniechań ścigania pozostaną poza polem rozważań.

2 Zob. art. 40 - 1 Code de procédure pénale, T.j. z dnia 1 sierpnia 2019 r. Źródło: https://www.legifrance.gouv.fr/affichCode.do?cidTexte=LEGITEXT000006071154\&dateT exte $=20190910$ [dostęp: 10.09.2019].

3 T. SCHEFfLer: O ius puniendi słów kilka. W: Varia doctrinalia. Red. Ł. MachaJ. Wrocław 2012, s. 40. 


\section{Relacja do zasady trafnego orzekania}

U podstaw rozstrzygania $\mathrm{w}$ procesie leży zasada trafnej reakcji karnej. M. Cieślak definiował ją następująco: (1) nikt winny nie powinien uniknąć odpowiedzialności, (2) nikt niewinny nie powinien ponieść odpowiedzialności, (3) nikt winny nie powinien ponieść odpowiedzialności większej niż ta, na którą zasłużył, (4) nikt winny nie powinien ponieść odpowiedzialności mniejszej niż ta, na którą zasłużył ${ }^{4}$. Kodeks postępowania karnego stawia zasadę trafnej reakcji karnej wśród normatywnych celów procesu na równi z postulatami uwzględnienia prawnie chronionych interesów pokrzywdzonego (art. $2 \S 1$ pkt 2 k.p.k.) oraz rozstrzygnięcia sprawy w rozsądnym terminie (art. $2 \S 1$ pkt 2 k.p.k.). Czyn sprawcy, będący przedmiotem badania $\mathrm{w}$ procesie karnym, przy braku negatywnych przesłanek procesowych, musi spotkać się z adekwatną reakcją. W ten sposób dokonuje się umocnienie poszanowania dla prawa i obowiązujących zasad współżycia społecznego ${ }^{5}$.

Obowiązywanie i funkcjonowanie zasady trafnego orzekania tradycyjnie wiąże się z przeprowadzeniem postępowania, przesądzeniem o odpowiedzialności prawnej oskarżonego i w razie pozytywnej weryfikacji tezy skargi - wymierzeniem adekwatnej sankcji. Współczesne realia procesu, w szczególności obowiązujący standard sprawiedliwości proceduralnej oraz zyskujące coraz większą popularność postulaty realizacji sprawiedliwości naprawczej każą rozważyć, czy nie należy na zasadę trafnego orzekania spojrzeć szerzej. Do realiów dzisiejszego procesu karnego nie przystaje wyrażające zasadę retrybutywizmu stwierdzenie, że wystarczające jest odpłacenie „złem” za wyrządzone zło ${ }^{6}$. Niezbędne jest przywrócenie naruszonego „dobra"”. Należy określić, czy w rzetelnym, sprawiedliwym procesie zaniechanie ścigania może stanowić trafną reakcję na popełnione przestępstwo, czy rzeczona instytucja jest nieakceptowalnym wyrazem oportunizmu i odpowiedzią na potrzeby praktyki. Jeśli zaniechanie ścigania stoi w sprzeczności z zasadą trafnego orzekania, to funkcjonowanie takiej instytucji w systemie prawnym jest z punktu widzenia spójności i aksjologii tego systemu nie do zaakceptowania.

${ }^{4}$ M. CIEŚLAK: Zagadnienie reformy prawa karnego. Pal. 1988, nr 5, s. 54.

${ }^{5}$ Wyrok SA w Łodzi z dnia 21 marca 2013 r., II AKa 31/13, Legalis.

${ }^{6}$ D. SzumiŁo-KulczycKa: Proces karny a idea sprawiedliwości naprawczej. W: System Prawa Karnego Procesowego. T. 1, cz. 2: Zagadnienia ogólne. Red. P. HofMAŃsKI. Warszawa 2013, s. 377.

7 Ibidem. 


\section{Instytucja zaniechania ścigania a umorzenie kompensacyjne}

Obecnie Kodeks karny i Kodeks postępowania karnego nie znają instytucji, którą można by określić mianem zaniechania ścigania warunkowanego prawną niecelowością wynikającą ze zrealizowania celów postępowania karnego jeszcze przed przeniesieniem sprawy na etap postępowania jurysdykcyjnego. Instytucja tego rodzaju była znana Kodeksowi karnemu do dnia 16 kwietnia 2016 r. Mowa o tzw. umorzeniu restytucyjnym (nazywanym także „umorzeniem kompensacyjnym”), o którym stanowił przepis art. 59a k.k. Zgodnie z powołanym przepisem, jeśli przed rozpoczęciem przewodu sądowego $\mathrm{w}$ pierwszej instancji sprawca, który nie był uprzednio skazany za przestępstwo umyślne z użyciem przemocy, pojednał się z pokrzywdzonym, w szczególności w wyniku mediacji i naprawił szkodę lub zadośćuczynił wyrządzonej krzywdzie, umarza się, na wniosek pokrzywdzonego, postępowanie karne o występek zagrożony karą nieprzekraczającą trzech lat pozbawienia wolności, a także o występek przeciwko mieniu zagrożony karą nieprzekraczającą pięciu lat pozbawienia wolności, jak również o występek określony w art. 157 § 1 k.k. Zgodnie z $\$ 2$ art. 59a k.k., jeśli w sprawie występował więcej niż jeden pokrzywdzony, dla skorzystania z dobrodziejstwa instytucji z art. 59a k.k. niezbędne było naprawienie szkód, bądź zadośćuczynienie za wyrządzone krzywdy wobec wszystkich pokrzywdzonych. Ostatni z paragrafów cytowanej jednostki przewidywał, że zastosowanie umorzenia restytucyjnego było niedopuszczalne, jeśli stałoby to w sprzeczności z potrzebą realizacji celów kary. W niedługim okresie swojego obowiązywania przepis art. 59a k.k. stał się przedmiotem licznych wypowiedzi przedstawicieli doktryny. Największe kontrowersje wzbudziła możliwość umarzania postępowań przez prokuratorów. Warto odnotować nietrafną moim zdaniem wypowiedź B. Myrny, który wskazał, że regulacja przepisu art. 59a k.k. była niezgodna z konstytucyjną zasadą sądowego wymiaru sprawiedliwości (art. 175 ust. 1 Konstytucji RP) i konstytucyjną, jak i ustawową zasadą domniemania niewinności (art. 42 ust. 2 Konstytucji RP w zw. z art. 5 $\S 1$ k.p.k. $)^{8}$. Niezgodność przepisu art. 59a k.k. z art. 175 ust. 1 Ustawy Zasadniczej miała zasadzać się na powierzeniu prokuratorowi władzy do zakończenia procesu karnego, w sytuacji, gdy taką władzę, zdaniem autora, powinien posiadać wyłącznie sąd. Nie zgadzam się z powyższym, bowiem sądowy wymiar sprawiedliwości, o którym mowa w art. 175 ust. 1 Konstytucji RP, to władza sądzenia, a więc - wiążącego rozstrzygania sporów o prawo, w których przynajmniej jedną ze stron jest jednostka lub

${ }^{8}$ B. Myrna: Artykut 59a k.k. - sukces czy porażka ustawodawcy. „Nowa Kodyfikacja Prawa Karnego" 2018, nr 50, s. 35-36. 
inny podmiot podobny ${ }^{9}$. Dyskrecjonalne uprawnienia organów postępowania karnego (nawet jeśliby poruczyć je wyłącznie prokuratorom) są wyrazem określonego poglądu ustawodawcy w zakresie preferencji wartości legalistycznych bądź oportunistycznych (zakresu swobody decyzji o celowości prowadzenia postępowania i dysponowania skargą karną), a nie niedopuszczalnego przerzucania sprawowania wymiaru sprawiedliwości na inne organy niż te, które wymieniono w art. 175 Konstytucji RP. Ścisły rozdział funkcji procesowych (rozstrzygania, ścigania i obrony) w zestawieniu z treścią odpowiednich zasad procesowych (art. 10 $\S 1$ k.p.k.) wyraźnie przesądza o tym, kto jest dysponentem skargi karnej i w czyjej kompetencji leży podejmowanie rozstrzygnięć o zaniechaniu ścigania, o ile te rozstrzygnięcia nie nakładają na sprawcę czynu zastępczych form odpowiedzialności. W świetle przepisu art. 59a k.k. prokurator był upoważniony do zakończenia wyłącznie tego etapu postępowania, którego był gospodarzem. W gruncie rzeczy jego uprawnienia niewiele różniły się od innych uprawnień dyskrecjonalnych, w które wyposażył go ustawodawca (art. $11 \S 1$ k.p.k.). Ważny głos w dyskusji zabrał J. Zagrodnik, który wskazał, że choć upoważnienie organu prokuratorskiego do umorzenia postępowania na wniosek pokrzywdzonego $\mathrm{w}$ rezultacie naprawienia szkody lub zadośćuczynienia krzywdzie przez sprawcę jest nie do pogodzenia z konstytucyjną zasadą sądowego wymiaru sprawiedliwości ${ }^{10}$, to mechanizm pokrewny przepisowi art. 59a k.k. mógłby znaleźć zastosowanie w polskim systemie prawnym pod warunkiem utrzymania wyłącznie sądowej kompetencji podejmowania decyzji o zaniechaniu ścigania ${ }^{11}$.

Przepis art. 59a k.k. utracił moc w dniu 15 kwietnia 2016 r. $^{12}$. Ustawodawca następująco uzasadniał jego uchylenie: „Wydaje się, że zarówno instytucja umorzenia restytucyjnego, określona w art. 59a k.k., jak również możliwość zastosowania nadzwyczajnego złagodzenia kary $\mathrm{z}$ uwagi na dobrowolne poddanie się karze czy wniosek o wydanie wyroku skazującego nie spełniają celów postępowania karnego w postaci

9 M. Masternak-Kubiak. W: Konstytucja Rzeczypospolitej Polskiej. Komentarz. Red. M. HaczKowsKa. Komentarz do art. 175. LEX/el. 2014 i cytowane tam orzecznictwo, w tym wyrok TK z dnia 1 grudnia 2008 r., P. 54/2007, LexisNexis nr 1968781 OTK-A 2008, nr 10, poz. 171.

10 J. ZAGRODNIK: O pojęciu „wymiaru sprawiedliwości” w kontekście umorzenia postępowania przygotowawczego na wniosek pokrzywdzonego (art. 59a k.k.). „Iustitia” 2015, nr 2, Legalis.

${ }^{11}$ Ibidem.

$12 \mathrm{Na}$ mocy krytykowanej przez przedstawicieli doktryny Ustawy z dnia 11 marca 2016 r. o zmianie ustawy - Kodeks postępowania karnego oraz niektórych innych ustaw, Dz.U. 2016, poz. 437. Dość wskazać, że zasadniczym celem przywołanej ustawy było odwrócenie zmian wprowadzonych do kodeksu w drodze „wielkiej nowelizacji”. 
odpłaty za popełnienie czynu zabronionego. Jakkolwiek postawa sprawcy po popełnieniu czynu czy jego zachowanie wobec pokrzywdzonego nie pozostają bez znaczenia $\mathrm{w}$ kontekście orzeczenia o karze, to nie powinny stanowić realnie samodzielnej podstawy do bardzo daleko idącego łagodzenia wymiaru kary. Nie wydaje się zatem uzasadnione utrzymywanie instytucji tzw. umorzenia restytucyjnego (art. 59a k.k.). Przede wszystkim umożliwia ono - poprzez względną obligatoryjność jego zastosowania uniknięcie odpowiedzialności karnej przez sprawców nawet poważnych przestępstw (w potocznym rozumieniu „wykupienie się” od odpowiedzialności), ponadto wymóg złożenia przez pokrzywdzonego odpowiedniego wniosku powoduje, że instytucja ta może służyć do wywierania niedozwolonej presji przez oskarżonych, ukierunkowanej na skłonienie pokrzywdzonego do jego złożenia"13.

Argumentacja projektodawców była ogólnikowa, nietrafna i daleka od sedna problemu. Legalizm nie jest wartością absolutną, a jego prymat $\mathrm{w}$ procesie nie powinien prowadzić do bezrefleksyjnego wnoszenia i popierania skarg w każdej sprawie. Trudno oprzeć się wrażeniu, że obawa przed uniknięciem przez sprawców odpowiedzialności jest wyrazem skrajnie legalistycznej postawy projektodawców, którzy twierdzą, że funkcjonowanie w systemie prawnym instytucji umorzenia restytucyjnego uniemożliwiało realizację celu kary w postaci odpłaty. Rzecz w tym, że kara kryminalna (a także, w szerszym kontekście - każda sankcja związana z przypisaniem odpowiedzialności za popełnione przestępstwo) znajduje uzasadnienie nie tylko w odpłacie. Ocena regulacji pozwalającej na zakończenie postępowania wyłącznie z punktu widzenia retrybutywizmu jest nie do zaakceptowania. W świetle art. $2 \S 1$ pkt 1-2 k.p.k. celem postępowania karnego jest zastosowanie wobec winnego takiej formy odpowiedzialności prawnej, która będzie adekwatna (trafna, słuszna) w relacji do wagi przypisanego czynu. Reakcja, z którą musi spotkać się sprawca, niekoniecznie musi być karą w rozumieniu rozdziału IV k.k. Zasada trafnej reakcji nie wymaga, by forma odzewu organów wymiaru sprawiedliwości była surowa czy odstraszająca - ma być jedynie adekwatna (odpowiednia, przystająca do wagi przewinienia). Projektodawcy wskazywali na „cel postępowania w postaci odpłaty". $Z$ art. 2 k.p.k. celu takiego nijak nie da się wyprowadzić. Odpłata nie jest również doktrynalnym celem procesu. Jeśli odpłata za popełniony czyn ma być surowa, to jest tak nie dlatego, że takiemu celowi ma służyć proces, ale z tego powodu, że taka sankcja jest adekwatna w świetle

${ }^{13}$ Uzasadnienie rządowego projektu ustawy o zmianie ustawy - Kodeks postępowania karnego oraz niektórych innych ustaw uchwalonej w dniu 11 marca 2016 r., druk sejmowy nr 207, s. 18. 
dyrektyw wymiaru kary. Rolą prawa procesowego nie jest dyktowanie postaci odpowiedzialności za przestępstwa, ale stworzenie warunków do tego, by przepisy prawa materialnego (statuujące warunki i podstawy odpowiedzialności za czyny zabronione) mogły być realizowane w procesie, który jest rzetelny, sprawiedliwy i prowadzony w warunkach równości stron. Prawo karne procesowe może stwarzać warunki ku temu, by realizacja norm prawa karnego materialnego nie stawała się koniecznością. Postępowanie karne (w szczególności we wczesnej fazie) może i powinno stanowić forum do zawierania porozumień pomiędzy jego stronami. Proces karny wyposażony w takie instrumentarium staje się samoistnym źródłem sprawiedliwych rozstrzygnięc ${ }^{14}$.Tym niemniej warto przytoczyć pogląd R. Kopra ${ }^{15}$, zgodnie z którym choć umorzenie restytucyjne było płaszczyzną urzeczywistniania się sprawiedliwości naprawczej, to wobec rezygnacji z realizacji norm prawa karnego materialnego stanowiło zaprzeczenie sprawiedliwości karnomaterialnej i zasady trafnej reakcji.

\section{Cechy konstytutywne instytucji zaniechania ścigania postępowania w procesie karnym}

Zarówno analiza dawnych rozwiązań krajowego systemu prawnego, jak i systemów obcych skłania do przekonania, że poddany analizie typ instytucji zaniechania ścigania charakteryzują następujące cechy: (1) uzależnia zaniechanie ścigania od zawarcia porozumienia procesowego przez strony postępowania, (2) znajduje zastosowanie głównie na etapie postępowania przygotowawczego, z wyjątkami na rzecz postępowania jurysdykcyjnego, (3) zakłada realizację celów postępowania pomimo nieprzeprowadzania procesu, (4) jej zastosowanie jest możliwe wyłącznie w procesie, w którym występują co najmniej dwie strony postępowania przygotowawczego, (5) nie jest wyrazem pełnego oportunizmu, (6) wiąże się z koniecznością kompensaty pokrzywdzonemu za popełniony czyn zabroniony, (7) nie prowadzi do przesądzenia o odpowiedzialności karnej sprawcy (nie przełamuje domniemania niewinności), (8) realizuje ideę sprawiedliwości naprawczej, (9) nawiązuje do modelu rozstrzygania o przedmiocie procesu poza rozprawą główną sensu largo.

14 J. SKoruPKa: O sprawiedliwości procesu karnego. LEX/el. 2013.

15 R. KOPER: Warunki umorzenia postępowania karnego $w$ trybie art. 59a KK. IN 2014, nr 3, s. 11-12. 


\subsection{Porozumienie procesowe}

Charakter prawny omawianego typu zaniechania ścigania ma swoje źródło w porozumieniu procesowym będącym formą zachowania uczestnika procesu, której przedmiotem jest uzgodnienie określonej kwestii, mającej choćby techniczne znaczenie dla przedmiotu procesu ${ }^{16}$ lub też, wedle węższej definicji, układ polegający na tym, że dwaj uczestnicy procesu w granicach swych uprawnień czynią sobie wzajemne ustępstwa co do toku postępowania lub rozstrzygnięcia merytorycznego ${ }^{17}$. Niewątpliwie zatem u podstaw decyzji o zaniechaniu ścigania może leżeć umowa zawarta co najmniej pomiędzy jednym pokrzywdzonym a jednym sprawcą czynu (nie ma podstaw ku temu, by dla zawarcia omawianego porozumienia sprawca musiał nabywać status podejrzanego ${ }^{18}$. Minimalną treścią porozumienia poprzedzającego zaniechanie ścigania jest: (1) ustalenie zakresu cywilnoprawnej odpowiedzialności sprawcy i wykonanie tak powstałego zobowiązania oraz (2) wystąpienie przez pokrzywdzonego $\mathrm{z}$ żądaniem zaniechania ścigania lub popieranie tego sposobu zakończenia postępowania. Porozumienie realizuje się zatem w minimalnej formule $d o$ ut des. Na gruncie podziału zaproponowanego przez S. Waltosia ${ }^{19} \mathrm{w}$ systemach prawnych, w których omawiana instytucja funkcjonuje, rzeczone porozumienia dają się określić jako formalne, natomiast w systemach nieznających instytucji zaniechania ścigania - jako paraformalne, zatem niemogące wywołać doniosłego skutku procesowego i mające znaczenie w głównej mierze dla wymiaru kary.

\subsection{Realizacja zasady sprawiedliwości naprawczej}

Porozumienie leżące u podstawy zaniechania ścigania znajduje swoje źródło w zasadzie sprawiedliwości naprawczej. Stosowanie powołanej instytucji w omawianym kształcie nie powinno zależeć od inicjatywy or-

16 S. SteInborn: Porozumienia $w$ polskim procesie karnym. Kraków 2005, s. 49, cyt. za: S. Waltoś: „Porozumienia” $w$ polskim procesie karnym de lege lata i de lege ferenda (Próba oceny dopuszczalności). PiP 1992, nr 7, s. 38.

17 Ibidem, cyt. za: A.R. ŚwiatŁowski: Koncepcja porozumień karnoprocesowych. PiP 1998, z. 2, s. 55.

18 Choć może to być uzasadnione z punktu widzenia gwarancji procesowych - racjonalny kształt instytucji bezwarunkowego umorzenia dopuszczającej zaniechanie ścigania jeszcze na etapie in rem musi zawierać dostateczne gwarancje dla osoby podejrzanej w szczególności w zakresie wyłączenia lub ograniczenia prokuratorskiego prawa do podjęcia postępowania. Podobne gwarancje powinny występować w wypadku zastosowania instytucji na etapie in personam.

19 S. Steinborn: Porozumienia..., s. 52, cyt. za: S. Waltoś: „Porozumienia”..., s. 38. 
ganu ścigania, a od woli samych stron postępowania przygotowawczego. Zainteresowanie tego rodzaju instytucjami będzie stale rosło. Składa się na to w głównej mierze wzrost znaczenia społeczeństwa obywatelskiego, zwiększanie się świadomości prawnej i wzrost znaczenia godności istoty ludzkiej ${ }^{20}$. Przekonanie stron postępowań karnych o zawłaszczaniu konfliktu sprawca - ofiara przez państwo postępuje. W sprawach drobnych świadczy o dalece posuniętym zbiurokratyzowaniu procesu karnego. Większość tego rodzaju spraw może być kompleksowo rozstrzygana za pomocą takich narzędzi jak kompensacja i koncyliacja. Jeśli charakterystyczny dla sprawiedliwości naprawczej trójkąt sprawca - pokrzywdzony - wspólnota ${ }^{21}$ funkcjonuje poprawnie, to brak w tym trójkącie miejsca dla sankcji państwowej. Rolą instytucji opartych na alternatywnych metodach rozstrzygania sporów i idei sprawiedliwości naprawczej nie jest całkowite wyparcie „klasycznej” drogi procesu karnego ${ }^{22}$, lecz wprowadzenie adekwatnych rozwiązań, w sprawach, w których jest na nie miejsce. Nierzadko sama postawa stron „postępowań prokuratorskich” w większości przypadków może doprowadzić do rozładowania napięcia społecznego, spowodowanego popełnionym czynem. Jeśli społeczeństwo samodzielnie wraca do stanu sprzed czynu, a zło zostaje naprawione, pytanie o konieczność realizacji norm prawa karnego i o ewentualny cel tej realizacji pozostaje pytaniem retorycznym.

\subsection{Związki z systemem merytorycznego rozstrzygania o przedmiocie procesu poza rozprawą główną}

Instytucja zaniechania ścigania wykazuje znaczne podobieństwa do modelu merytorycznego rozstrzygania o przedmiocie procesu poza rozprawą główną w szerokim rozumieniu. Twórca pojęcia - H. Paluszkiewicz - wskazuje, że merytorycznym orzekaniem o przedmiocie procesu poza rozprawą główną jest szereg instytucji prawnych o wspólnym, prakseologicznie spójnym, jednakowo uzasadnianym aksjologicznie korzeniu, które polegają na orzeczeniu o odpowiedzialności karnej sprawcy wyrokiem na forum posiedzenia ${ }^{23}$.

20 S. SzoŁUcha: „Sprawiedliwość restaurujaca” jako możliwy, alternatywny cel procesu karnego. W: Wspótczesne tendencje $w$ rozwoju procesu karnego z perspektywy dogmatyki oraz teorii i filozofii prawa. Red. J. SKorupKa, I. Hayduk-HaWrYLaK. Warszawa 2011, s. 184.

${ }^{21}$ Ibidem, s. 186.

22 D. Szumito-KulczycKa: Proces..., s. 379.

${ }^{23}$ H. PaluszKIEWicz: W poszukiwaniu uzasadnienia aksjologicznego dla karnoprocesowej instytucji pierwszoinstancyjnego merytorycznego wyrokowania poza rozprawa. W: Wspótczesne tendencje w rozwoju procesu karnego..., s. 215 i 218. 
Zaniechanie ścigania motywowane zawarciem porozumienia procesowego, mimo że nie przenosi sprawy do postępowania sądowego, pozwala na jej merytoryczne zakończenie. Decyzja wydawana jest w oparciu o względy celowości, w oderwaniu od klasycznej drogi weryfikacji faktycznej podstawy procesu ${ }^{24}$ (całokształtu informacji o faktach, które pozwalają na rekonstrukcję określonego wycinka rzeczywistości na potrzeby zainicjowania i prowadzenia postępowania). Decyzja o zaniechaniu ścigania $\mathrm{w}$ omawianym modelu powinna być motywowana przekonaniem o częściowej realizacji celów procesu, mimo dyskontynuacji postępowania. Podobnie zatem jak w modelu merytorycznego orzekania o przedmiocie procesu poza rozprawą główną minimalizacja postępowania nie powoduje znacznego uszczerbku dla realizacji jego celów. Instytucja zaniechania ścigania jest podobna do modelu merytorycznego orzekania poza rozprawą główną również z punktu widzenia realizowanych wartości: nieinstrumentalnej $\mathrm{w}$ postaci rzetelności procesu i instrumentalnych $\mathrm{w}$ postaci szybkości i sprawności postępowania, równości stron procesowych, prawa do zaskarżenia decyzji kończącej postępowania oraz - co należy podkreślić - współkształtowania przez sprawcę własnej odpowiedzialności za popełniony $\mathrm{czyn}^{25}$.

\subsection{Forum}

Jedną z bardziej charakterystycznych cech omawianej instytucji jest jej występowanie na etapie postępowania przygotowawczego. Zaniechanie ścigania $\mathrm{w}$ naturalny sposób wiąże się $\mathrm{z}$ realizacją dyskrecjonalnych uprawnień prokuratorów $\mathrm{w}$ postaci władzy decydowania o celowości prowadzenia postępowań $\mathrm{w}$ określonych grupach spraw. Omawiana postać zaniechania ścigania opiera się na porozumieniu zawieranym między podmiotami uwikłanymi w przestępstwo. Stąd postępowanie przygotowawcze jest „naturalnym forum” do podejmowania decyzji o zaniechaniu ścigania, skoro jego stronami są pokrzywdzony i podejrzany (art. 299 $\S 1$ k.p.k.). Stosowanie omawianej instytucji jest kontrowersyjne w wypadku tzw. przestępstw bez ofiar. Wówczas zaniechanie prawnie dopuszczalnego ścigania mogłoby być motywowane brakiem interesu publiczne-

${ }^{24}$ P. HofmańsKi, M. Jeż-LudwichowsKa: Wzajemny stosunek pojęcia przesłanek procesu (warunków dopuszczalności procesu i podstawy faktycznej procesu). W: System Prawa Karnego Procesowego. T. IV: Dopuszczalność procesu. Red. P. Hofmański, M. Jeż-Ludwichowska, A. LACH. LEX/el. 2016.

${ }^{25}$ H. PaluszKiewicz: W poszukiwaniu..., s. 227. 
go, jak chociażby w krajach o utartej tradycji oportunistycznej (Francja, Szwecja, Holandia ${ }^{26}$ ).

Nie należy jednak tracić z pola widzenia, że istniejąca na gruncie k.k.s. instytucja dobrowolnego poddania się odpowiedzialności - ze względu na brak wpisu do Krajowego Rejestru Karnego podobna w skutkach do zaniechania ścigania - zakłada możliwość zakończenia postępowania bez negatywnych dla sprawcy skutków skazania, mimo że w sprawie nie występuje pokrzywdzony. Między zaniechaniem ścigania powodowanym zawarciem porozumienia a dobrowolnym poddaniem się odpowiedzialności istnieje zasadnicza różnica. Mimo że wyrok wydany w postępowaniu, o którym mowa w rozdziale 16 k.k.s., przesądza o realizacji znamion konkretnego typu czynu i w świetle art. 17 § 1 k.k.s. przełamuje domniemanie niewinności ${ }^{27}$ - to nie prowadzi do wystąpienia negatywnych skutków skazania. Cel postępowania realizuje się jednak w uiszczeniu wymaganej należności publicznoprawnej (art. $17 \S 1$ pkt $1 \mathrm{w}$ zw. z art. $114 \S 1$ k.k.s.). Dobrowolne poddanie się odpowiedzialności mimo swojej specyfiki nie stanowi jakiegokolwiek wyłomu od zasady legalizmu (art. 10 § 1 k.p.k.). Sprawca ponosi bowiem odpowiedzialność, a interes fiskalny Skarbu Państwa zostaje zaspokojony. Mimo podobieństwa skutków prawnych zaniechanie ścigania i dobrowolne poddanie się odpowiedzialności stanowią odmienne instytucje prawne.

Tym samym zaniechanie ścigania $\mathrm{w}$ opisywanej wersji nie powinno stanowić reakcji na „przestępstwa bez ofiar” na gruncie prawa karnego powszechnego. Nie wykluczam stosowania zaniechania ścigania i w takim wypadku, tym niemniej powinno być ono połączone $\mathrm{z}$ zastosowaniem alternatywnych środków reakcji na przestępstwo lub wynikać z dopuszczonej przez ustawodawcę preferencji wartości oportunistycznych. Tymczasem sens instytucji zaniechania ścigania $w$ opisywanej wersji na etapie postępowania przygotowawczego uzasadniony jest dbałością o dynamikę postępowania i względem na zawarcie przez sprawcę i pokrzywdzonego porozumienia.

Analiza obcych systemów prawnych każe przyjąć, że omawiany mechanizm powinien funkcjonować w głównej mierze na forum postępowania przygotowawczego. Określony w $§ 220$ słowackiej ustawy karnoprocesowej ${ }^{28}$ „Zmier” (pojednanie) dopuszcza zastosowanie mechanizmu zaniechania ścigania przez prokuratora $\mathrm{w}$ sprawie o przestępstwo za-

${ }^{26}$ E. Luna, M. WAdE: Prosecutors as judges. "Washington and Lee Law Review" 2010, No. 67 , s. 1443.

${ }^{27}$ Choć stosowana reakcja ma charakter czysto formalny, na co słusznie wskazuje E. Hryniewicz-Lach: Kompensacja szkód i krzywd w prawie karnym. PiP 2016, nr 3, Legalis.

28 Trestný Poriadok z 24. mája 2005 (130/2005 Z. z.) [dalej jako: T.p.]. Źródło: https://www.slov-lex.sk/pravne-predpisy/SK/ ZZ/2005/130/ [dostęp: 22.06.2018]. 
grożone karą nieprzekraczającą pięciu lat pozbawienia wolności, o ile sprawca: (1) przyznaje się do popełnienia czynu zabronionego, a nie ma powodów do tego, aby przypuszczać, że jego oświadczenie zostało wydane w stanie wyłączającym świadome lub swobodne wyrażenie woli, (2) naprawił szkodę lub podjął czynności zmierzające do jej naprawienia bądź w inny sposób usunął negatywne skutki przestępstwa, (3) wpłacił na rachunek sądu właściwego do rozpoznania sprawy, a w postępowaniu przygotowawczym na rachunek właściwej jednostki prokuratury, sumę określoną przez Ministerstwo Ochrony i Wsparcia Ofiar Przestępstw, a suma ta przystaje do wagi popełnionego czynu ${ }^{29}$. Analogiczny mechanizm przewiduje prawo niemieckie $-\mathrm{w} \S 153 \mathrm{a} \mathrm{StPo}^{30}$, zgodnie z którym: $\mathrm{w}$ sprawie o przestępstwo prokurator jest uprawniony do tego, aby za zgodą podejrzanego i sądu właściwego do rozpoznania sprawy zaniechać wnoszenia skargi do sądu, nakładając jednocześnie na podejrzanego obowiązki, eliminując w ten sposób interes publiczny w ściganiu, jeśli stopień winy nie stoi temu na przeszkodzie. Omawiany przepis zakłada otwarty katalog obowiązków, od których ustawa uzależnia wyeliminowanie interesu w ściganiu, wskazując między innymi na: realizację obowiązku naprawienia szkody - w formie świadczenia, zapłaty sumy pieniężnej na rzecz organizacji pożytku publicznego, bądź Skarbu Państwa, czy też wykonanie ugody zawartej z pokrzywdzonym. Rzeczone obowiązki podejrzany musi wykonywać przez lub musi wykonać w ciągu 6 miesięcy lub roku (w zależności od ich charakteru). Po pomyślnym upływie „okresu próby" prokurator traci prawo do wniesienia skargi (§ 153a ust. 7 zd. 4 StPo). Jest to zatem instytucja quasi-probacyjna. Znamienne, że prawo niemieckie dopuszcza stosowanie instytucji z § 153a StPo również wówczas, gdy w sprawie nie występuje pokrzywdzony. Taki kształt $\$ 153$ a StPo może jednak otwierać drogę do stawiania słusznych zarzutów umożliwiania sprawcom wykupienia się od odpowiedzialności za popełniony czyn. W doktrynie niemieckiej podkreśla się, że instytucja z $§ 153$ StPo jest wyrazem rezygnacji z prawa karania, podyktowanego głównie względami ekonomiki procesowej, jednak ze względem na porozumienie stron postępowania przygotowawczego, które zawsze leży u jej podstawy ${ }^{31}$.

${ }^{29}$ Więcej o instytucji pojednania - M. BASA: Mechanizmy kompensacyjno-konsensualne $w$ polskim k.p.k. i słowackim Trestným Poriadoku - analiza prawnoporównawcza. „Internetowy Przegląd Prawniczy TSBP UJ” 2018, nr 3, s. 5-18.

${ }^{30}$ Niemiecka ustawa karnoprocesowa - Strafprozeßordnung [StPO] zuletzt geändert durch Art. 12 G v. 18.12.2018 I 2639. Źródło: https://www.gesetze-im-internet.de/stpo/ BJNR006290950.html\#BJNR006290950BJNG000102311 [dostęp: 16.02.2019].

31 B. Sсhмitt. W: L. Meyer-Gossner, B. Schmitt: Strafprozessordnung Gerichsverfassungsgesetz, Nebengesetze und ergänzende Bestimmungen. München 2014, s. 749 . 
Charakter i sposób działania opisanych instytucji umożliwiających organom ścigania podejmowanie dyskrecjonalnych decyzji o dyskontynuacji postępowania przesądza o trafności ich umiejscowienia na etapie postępowania przygotowawczego.

\subsection{Zagadnienie realizacji celów postępowania}

Kolejną z fundamentalnych cech instytucji zaniechania ścigania jest częściowa realizacja celów procesu karnego, pomimo jego faktycznego nieprowadzenia. Nie bez racji podnosi się, że realizacja celów postępowania możliwa jest wyłącznie w procesie przeprowadzonym w pełni (zainicjowanym właściwą skargą, prowadzonym przed właściwym sądem i zakończonym wyrokiem skazującym). W najszerszym ujęciu - każdy proces rozpoczęty skargą zasadniczą i niezakończony skazaniem sprawcy świadczy o niezrealizowaniu jego celów. W modelowym procesie akty oskarżenia powinny być wnoszone wyłącznie zasadnie, materiał dowodowy na ich poparcie powinien być kompletny i potwierdzać tezę skargi. Jest to jednak założenie idealizujące - szereg procesów, w których zasadnie wniesiono akty oskarżenia, nie prowadzi do wydania wyroków skazujących (choćby z uwagi na faktyczne ograniczenia zasady prawdy materialnej), a inne procesy, w których dochodzi do prawomocnego i słusznego skazania (w rozumieniu przesądzenia o winie oskarżonego), znamienne są niewłaściwym doborem sankcji, zignorowaniem interesów pokrzywdzonego czy przewlekłością. Trafne rozstrzygnięcie w kwestii winy nie warunkuje zatem pełnej i właściwej realizacji celów postępowania. Instytucja zaniechania ścigania spowodowanego zawarciem porozumienia może przyczyniać się do częściowej realizacji celów postępowania przy jednoczesnym zagwarantowaniu jego szybkości. Warunki do zaniechania ścigania moga ujawnić się już wówczas, gdy w sprawie ujawniono pokrzywdzonego i podejrzanego, a podmioty te rozpoczęły negocjacje $\mathrm{w}$ przedmiocie warunków kompensaty za szkodę wyrządzoną przestępstwem. Zwiększenie dyspozycyjności stron $\mathrm{w}$ postępowaniu przygotowawczym może przeciwdziałać jego przewlekłości. Stronom niewątpliwie będzie zależeć na szybkim zakończeniu postępowania przygotowawczego (wydanie decyzji o zaniechaniu ścigania - po stronie podejrzanego, oraz uzyskanie kompensaty - po stronie pokrzywdzonego). To strony swoimi działaniami będą zmierzały do ugodzenia przedmiotu sporu, a rolą organu ścigania będzie wyłącznie wydanie decyzji o zaniechaniu ścigania, co gwarantuje dynamiczne postępowanie w sprawach drobnych.

Instytucja zaniechania ścigania może również przyczyniać się do realizacji celu procesu wyrażonego $\mathrm{w}$ art. 2 § 2 pkt 2 k.p.k. w postaci trafnego 
stosowania środków przewidzianych w prawie karnym oraz ujawniania okoliczności sprzyjających popełnieniu przestępstwa, co ma służyć osiągnięciu zadań postępowania karnego nie tylko w zwalczaniu przestępstw, lecz również $\mathrm{w}$ zapobieganiu im oraz $\mathrm{w}$ umacnianiu poszanowania prawa i zasad współżycia społecznego. Zaniechanie ścigania poprzedzone zawarciem porozumienia $\mathrm{w}$ większym stopniu umacnia poszanowanie prawa i zasad współżycia społecznego, niż realizuje funkcje profilaktyczne i prewencyjne. Wszystkich wartości wyrażonych w art. 2 § 2 pkt 2 k.p.k. nie da się ani w pełni pogodzić, ani zrealizować w jednakowym stopniu. Należy podkreślić, że każdy ze sposobów zakończenia postępowania karnego (po przeprowadzeniu rozprawy czy też poprzez merytoryczne rozstrzygnięcie wydane poza rozprawą główną) realizuje wartości wyrażone $\mathrm{w}$ art. $2 \S 1$ pkt 2 k.p.k. jedynie w określonej proporcji. Trudno bowiem wyobrazić sobie, by wyrok konsensualny w sprawie o kradzież w typie podstawowym, w którym oskarżony uzyskuje „premię na sankcji”, miał charakter wychowawczy, ogólnoprewencyjny i jednocześnie profilaktyczny. Nie inaczej jest $z$ instytucją zaniechania ścigania. Rzecz jednak w tym, że omawiana instytucja w omawianej wersji (skoro warunkiem jej bytu jest realna kompensata) będzie podkreślać wychowawczy cel postępowania karnego. W konsekwencji opisywany wariant zaniechania ścigania ma szerszy społeczny wydźwięk. Skoro bowiem warunkiem zastosowania rzeczonej instytucji jest pojednanie i kompensata, to ogólnospołeczny wymiar postępowania karnego ${ }^{32}$ rysuje się nie jako obraz surowej odpłaty, a jako forum pojednania i naprawy szkód. Nie może jednak ujść uwadze, że charakter instytucji zaniechania ścigania de facto uniemożliwia realizację funkcji profilaktycznej postępowania w jej tradycyjnym rozumieniu ${ }^{33}$. Stając w obronie opisywanej instytucji, należy wskazać, że niepełna, choć pewna realizacja celu wyrażonego w art. $2 \S 1$ pkt 2 k.p.k. jest bardziej wartościowa niż realizacja pełna, choć jedynie potencjalna.

Zaniechanie ścigania jest jedną z doskonalszych gwarancji zachowania interesów pokrzywdzonego (realizując cel wyrażony w art. $2 \S 1$ pkt 3 k.p.k.). Przyjmując, że kompensata za wyrządzoną szkodę jest zasadniczym dążeniem pokrzywdzonego $\mathrm{w}$ procesie, to zaniechanie ścigania oparte na porozumieniu realizuje rzeczony cel w sposób najdoskonalszy spośród znanych instytucji - z uwagi na fakt, że realne naprawienie szkody warunkuje byt omawianej instytucji. Trudno nie dostrzec innej, jeszcze ważniejszej funkcji zaniechania ścigania - realnej możliwości uniknię-

32 Sprowadzający się do postulatu kształtowania społecznie pożądanych postaw tak: J. Kosonoga. W: Kodeks postępowania karnego. T. I: Komentarz do art. 1-166. Red. R. StefańsKi, S. ZabŁOCKI. LEX/el. 2017, komentarz do art. 2 k.p.k.

${ }_{33} \mathrm{Tj}$. ujawniania źródeł przestępstwa, co stwarzać ma lepsze możliwości zwalczania określonej przestępczości i eliminowania czynników kryminogennych - ibidem. 
cia wtórnej wiktymizacji pokrzywdzonego. Zakończenie postępowania ze względu na zawarcie przez jego strony porozumienia pozwala na merytoryczne sfinalizowanie procesu bez konieczności udziału pokrzywdzonego $\mathrm{w}$ jakiejkolwiek czynności dowodowej. Jest to istotna jakościowo zmiana w porównaniu do procesu w „tradycyjnym wydaniu”, w którym pokrzywdzony wielokrotnie uczestniczy w nierzadko upokarzających dla niego czynnościach dowodowych (przesłuchania, oględziny ciała, okazania, konfrontacje). Ograniczenie udziału pokrzywdzonego w czynnościach postępowania ma niebagatelne znaczenie, skoro celem procesu jest nie tylko „uwzględnienie prawnie chronionych interesów pokrzywdzonego”, ale i - od 8 kwietnia 2015 r. $^{34}$ - „zachowanie jego godności” ${ }^{35}$. Nie można bez odpowiedzi pozostawić pytania, jak ma się decyzja o zaniechaniu ścigania do oczekiwań pokrzywdzonego co do określonego wymiaru kary. Wśród dążeń pokrzywdzonego w procesie znaczenie ma nie tylko uzyskanie kompensaty i pojednania, ale i dążenie do ukarania sprawcy ${ }^{36}$. Nie jest wykluczone, że pokrzywdzony popierając oskarżenie będzie dążył do wymierzenia sprawcy surowej kary, ale sytuacja taka ma miejsce głównie w sprawach o znacznym ciężarze gatunkowym. Do tych z kolei nie może mieć zastosowania zaniechanie ścigania. Nie należy wykluczać istnienia „pola niczyjego”, jednak i w takim przypadku można odwołać się do pryncypiów - skoro zaniechanie ścigania poprzedza zawarcie porozumienia, to pokrzywdzony, który je zawiera, samodzielnie i świadomie rezygnuje z prawa do popierania oskarżenia na rzecz koncyliacji.

\subsection{Relacja do wybranych zasad procesowych}

Ocena relacji instytucji zaniechania ścigania do zasady legalizmu nie jest jednoznaczna. Za istotę oportunizmu procesowego przyjmuje się twierdzenie, że organ procesu jest uprawiony do zaniechania ścigania, gdy $\mathrm{w}$ jego dyskrecjonalnej ocenie jest ono niecelowe, mimo istnienia faktycznych i prawnych przesłanek do podjęcia ścigania ${ }^{37}$. Pojmując oportunizm

${ }^{34}$ Zmiana wprowadzona w art. 20 pkt 1 Ustawy z dnia 28 listopada 2014 r. o ochronie i pomocy dla pokrzywdzonego i świadka, Dz.U. 2015, poz. 21.

35 Jak wskazuje się $\mathrm{w}$ literaturze - mowa o nakazie kierowanym do organu procesowego, by nie traktować osoby pokrzywdzonego w sposób przedmiotowy, ale uwzględniać jej uczucia i niejednokrotnie trudną sytuację psychiczną wynikłą z faktu popełnienia przestępstwa - tak: J. Grajewski, S. Steinborn. W: L. PAprzycki: Komentarz aktualizowany do art. 1-424 Kodeksu postępowania karnego. LEX/el. 2015, komentarz do art. 2 k.p.k.

${ }^{36}$ K. DUDKa: Rola pokrzywdzonego we wspótczesnym procesie karnym. W: Współczesne tendencje $w$ rozwoju procesu karnego..., s. 176.

${ }^{37}$ M. Rogacka-Rzewnicka: Oportunizm i legalizm ścigania przestępstw $w$ świetle wspótczesnych przeobrażeń procesu karnego. Warszawa 2007, s. 72. 
w ten sposób i uznając go za proste zaprzeczenie zasady legalizmu ${ }^{38}$, można by przyjąć, że omawiany wariant zaniechania ścigania ma właśnie taki charakter. Jednak współcześnie brak systemów prawnych jednolicie oportunistycznych czy jednolicie legalistycznych ${ }^{39}$. Brak możliwości jasnego wytyczenia granicy między powołanymi zasadami powoduje, że instytucje, które pozwalają na zaniechanie ścigania, lecz na określonych warunkach (zawarcie porozumienia procesowego, poniesienie zastępczej formy odpowiedzialności) mają charakter mieszany. Można zatem uznać, że omawiany model zaniechania ścigania ma charakter legalistyczno-oportunistyczny. O ile bowiem sprawca zostaje zwolniony z odpowiedzialności karnej za popełnione przestępstwo, o tyle chcąc skorzystać z dobrodziejstwa omawianej instytucji, musi ponieść odpowiedzialność cywilną (ponieść ją rzeczywiście - nierzadko inaczej niż wtedy, gdy naprawienie szkody orzekane jest jako środek kompensacyjny - art. 46 § 1 k.k., bądź probacyjny - art. $72 \S 2$ k.k. ${ }^{40}$. Przy tym należy pamiętać, że zarówno odpowiedzialność karna, jak i odpowiedzialność cywilna za popełnione przestępstwo są przedmiotami procesu karnego ${ }^{41}$. Nieponiesienie odpowiedzialności karnej nosi zatem znamiona jedynie częściowego odstępstwa od zasady legalizmu. Omawiane zagadnienie jest też do pewnego stopnia warunkowane ułomnością konstrukcji - współczesna definicja zasady oportunizmu nie obejmuje dopuszczonych w szerokim zakresie $\mathrm{w}$,systemach oportunistycznych” form merytorycznego rozstrzygania o przedmiocie procesu przez organ ścigania ${ }^{42}$.

Omawiana postać zaniechania ścigania wyklucza jednak realizację zasady kontradyktoryjności. Kontradyktoryjność postrzega się jako rdzeń procesu karnego, fundamentalną zasadę dotyczącą jego biegu, gwarancję prawidłowości ustaleń faktycznych i rękojmię rzetelności postępowania.

38 Który to pogląd kontestuje cytowana autorka - ibidem, s. 73.

${ }^{39}$ Ibidem, s. 74.

${ }^{40}$ Samo orzeczenie obowiązku naprawienia szkody (czy to tytułem środka kompensacyjnego, czy środka probacyjnego) nie skutkuje wykonanie nałożonego obowiązku. Sprawca może się od niego skutecznie uchylać. Zgoła inaczej jest w przypadku bezwarunkowego umorzenia postępowania - wówczas rzeczywiste naprawienie szkody jest warunkiem koniecznym zastosowania instytucji.

${ }^{41}$ Odpowiednio: głównym i ubocznym - tak: J. SkоRupKa.W: Kodeks postępowania karnego. Komentarz. Red. IDEM. Legalis 2018, komentarz do art. 1 k.p.k. oraz P. HofMAŃsKI. W: Kodeks postępowania karnego. Komentarz do art. 1-296. T. I. Red. IDEM. Legalis 2011, komentarz do art. 1 k.p.k., cyt. za: M. CiEśLAK: Polska procedura karna. Kraków 1971 s. 54; Z. Gostyński, S. Zabeocki. W: Bratoszewski et al.: Kodeks. T. I. Warszawa 2000, s. 186; K. Marszae. W: K. Marszae, S. Stachowiak, K. Zgryzek: Proces karny. Poznań 1996, s. 24; S. Waltoś: Proces karny. Zarys systemu. Warszawa 2008, s. 16. Zob. również: J. HeLIos: Tradycyjne i nowoczesne sposoby pojmowania „procedury”. „Acta Universitatis Wratislaviensis. Przegląd Prawa i Administracji”. T. 74. Wrocław 2006, s. 161.

${ }^{42}$ M. Rogacka-Rzewnicka: Oportunizm..., s. 81. 
Przyczyną wyłączenia możliwości realizacji zasady kontradyktoryjności $\mathrm{w}$ procesie zakończonym decyzją o zaniechaniu ścigania jest nieprzenoszenie sprawy na forum postępowania sądowego, które ma być areną kontradyktoryjnej walki oskarżonego i oskarżyciela. Minimalizacja pierwszego etapu procesu przyczynia się do wyłączenia realizacji zasady kontradyktoryjności w postępowaniu sądowym i ograniczeniu jej w postępowaniu przygotowawczym. Decyzja o zaniechaniu ścigania uniemożliwia prowadzenie sporu przez pokrzywdzonego i podejrzanego. Powyższe nie oznacza jednak, że w postępowaniu, w którym dochodzi do zaniechania ścigania, pogwałcone zostaną te wartości, które zabezpiecza kontradyktoryjność. Gwarancją rzetelności minimalizowanego postępowania staje się dyspozycyjność. Oddanie sprawy w ręce stron i umożliwienie zawarcia porozumienia prowadzi do wymiany argumentów na etapie jego negocjowania. Strony zatem konfrontują swoje stanowiska, tyle tylko, że nie w warunkach sporu prowadzonego na rozprawie. Pokrzywdzony i sprawca staraja się w warunkach kooperacji ustalić kształt ugody, która będzie stanowiła fundament decyzji o zaniechaniu ścigania. Rolą prokuratora będzie nie tylko ocena tego, czy z punktu widzenia celów postępowania zaniechanie ścigania jest zasadne, lecz także weryfikacja tego, czy negocjowano w warunkach, które nie uchybiają standardowi rzetelności procesu. Minimalizacja postępowania i zwiększenie jego dyspozycyjności nie zwalnia organu ścigania z konieczności baczenia na to, aby toczyło się ono na podstawie i w granicach prawa (art. 7 Konstytucji RP).

\section{Podsumowanie}

Zdefiniowanie instytucji zaniechania ścigania nie jest zadaniem łatwym, tym bardziej że przedmiotem wywodu były rozważania na temat mechanizmu prawnego, którego nie znają obowiązujące ustawy. Odwołanie się do uchylonego przepisu art. 59a k.k. i regulacji zagranicznych systemów prawnych pozwala na określenie, jaki kształt powinno przyjąć zaniechanie ścigania oparte na porozumieniu procesowym.

Przez instytucję zaniechania ścigania należy zatem rozumieć złożony mechanizm prawny o charakterze materialno-procesowym, legalistyczno-oportunistycznym, zgodny z zasadą trafnego orzekania, pozwalający organowi prokuratorskiemu na wydanie decyzji o zaniechaniu ścigania, na każdym etapie postępowania przygotowawczego, ze względu na pojednanie się przez sprawcę i pokrzywdzonego i zawarcie porozumienia procesowego, którego przedmiotem jest wyrażenie zgody na umorzenie postępowania, ustalenie sposobu kompensaty za wyrządzoną krzywdę lub spowodowaną szkodę i wykonanie tak powstałego zobowiąza- 
nia o cechach podobnych do mechanizmów funkcjonujących w modelu merytorycznego rozstrzygania o przedmiocie procesu poza rozprawą główną.

Jedną z najistotniejszych cech instytucji zaniechania ścigania jest kompromisowe łącznie wartości reprezentowanych przez zasadę legalizmu i oportunizmu. Opisany kształt instytucji dowodzi, że cele procesu karnego mogą być zrealizowane w większej części pomimo nieprzypisania sprawcy odpowiedzialności za popełniony czyn - a nawet nierozstrzygania o tym, czy czyn będący przedmiotem badania w postępowaniu rzeczywiście jest przestępstwem. Badany wariant zaniechania ścigania jest wyrazem zmieniających się tendencji w prawie karnym procesowym i coraz większego znaczenia mechanizmów kompensacyjno-koncyliacyjnych, a także minimalizacji i dejurydyzacji procesu. Stanowi dowód zmiany spojrzenia na rolę postępowania karnego w sprawach o czyny drobne. Funkcjonowanie $\mathrm{w}$ danym systemie prawnym instytucji zaniechania ścigania lub chociażby instytucji pokrewnej świadczy o dojrzałości danego systemu i zdrowej polityce penalnej państwa.

\section{Bibliografia}

\section{Literatura}

BASA M.: Mechanizmy kompensacyjno-konsensualne $w$ polskim k.p.k. $i$ stowackim Trestným Poriadoku - analiza prawnoporównawcza. „Internetowy Przegląd Prawniczy TSBP UJ" 2018, nr 3.

CIEŚLAK M.: Polska procedura karna. Kraków 1971.

CIEŚLAK M.: Zagadnienie reformy prawa karnego. Pal. 1988, nr 5.

DUDKA K.: Rola pokrzywdzonego we wspótczesnym procesie karnym. W: Wspótczesne tendencje $w$ rozwoju procesu karnego z perspektywy dogmatyki oraz teorii i filozofii prawa. Red. J. SKORUPKA, I. HAYDUK-HAWrYLAK. Warszawa 2011.

GostyŃsKi Z., ZabŁocki S. W: BratoszeWsKi et al.: Kodeks. T. I. Warszawa 2000.

GrajeWski J., Steinborn S. W: PAPRZyCKI L.: Komentarz aktualizowany do art. 1-424 Kodeksu postępowania karnego. LEX/el. 2015.

Helios J.: Tradycyjne $i$ nowoczesne sposoby pojmowania „procedury”. „Acta Universitatis Wratislaviensis. Przegląd Prawa i Administracji”. T. 74. Wrocław 2006.

HofMaŃsKi P. W: Kodeks postępowania karnego. Komentarz do art. 1-296. T. I. Red. IDEM. Legalis 2011.

HofMAŃsKi P., Jeż-LudwichowsKa M.: Wzajemny stosunek pojęcia przesłanek procesu (warunków dopuszczalności procesu i podstawy faktycznej procesu). W: System Prawa Karnego Procesowego. T. IV: Dopuszczalność procesu. Red. P. HofmańsKi, M. Jeż-LudwichowsKa, A. LACH. LEX/el. 2016.

Hryniewicz-Lach E.: Kompensacja szkód $i$ krzywd w prawie karnym. PiP 2016, nr 3. 
Koper R.: Warunki umorzenia postępowania karnego $w$ trybie art. 59 a KK. IN 2014, nr 3.

Kosonoga J. W: Kodeks postępowania karnego. T. I: Komentarz do art. 1-166. Red. R.A. STEFAŃsKi, S. ZabŁOCKI. LEX/el. 2017.

KURDELEK J.: Umorzenie „rejestrowe” dochodzenia - uwagi praktyczne. PiP 2011, nr 3, Legalis.

Luna E., Wade M.: Prosecutors as judges. "Washington and Lee Law Review" 2010, No. 67.

Masternak-Kubiak M. W: Konstytucja Rzeczypospolitej Polskiej. Komentarz. Red. M. НасzкоwsKa. LEX/el. 2014.

Meyer-Gossner L., SCHMitT B.: Strafprozessordnung Gerichsverfassungsgesetz, Nebengesetze und ergänzende Bestimmungen. München 2014.

Myrna B.: Artykut 59a k.k. - sukces czy porażka ustawodawcy. „Nowa Kodyfikacja Prawa Karnego" 2018, nr 50.

PALUSZKIEWICZ H.: W poszukiwaniu uzasadnienia aksjologicznego dla karnoprocesowej instytucji pierwszoinstancyjnego merytorycznego wyrokowania poza rozprawa. W: Wspótczesne tendencje $w$ rozwoju procesu karnego z perspektywy dogmatyki oraz teorii i filozofii prawa. Red. J. Skorupka, I. Hayduk-Hawrylak. Warszawa 2011.

Rogacka-RzEwnicka M.: Oportunizm i legalizm ścigania przestępstw $w$ świetle współczesnych przeobrażeń procesu karnego. Warszawa 2007.

SCHEFfler T.: O ius puniendi słów kilka. W: Varia doctrinalia. Red. Ł. MACHAJ. Wrocław 2012.

SKorupKa J. W: Kodeks postępowania karnego. Komentarz. Red. IDEM. Legalis 2018.

SKoRUPKA J.: O sprawiedliwości procesu karnego. LEX/el. 2013.

STEINBORN S.: Porozumienia $w$ polskim procesie karnym. Kraków 2005.

SzoŁUCHA S.: „Sprawiedliwość restaurujaca” jako możliwy, alternatywny cel procesu karnego. W: Wspótczesne tendencje $w$ rozwoju procesu karnego z perspektywy dogmatyki oraz teorii i filozofii prawa. Red. J. SKorupKa, I. Hayduk-Hawrylak. Warszawa 2011.

SzumiŁo-KulczycKa D.: Proces karny a idea sprawiedliwości naprawczej. W: System Prawa Karnego Procesowego. T. 1, cz. 2: Zagadnienia ogólne. Red. P. HofMAŃsKI. Warszawa 2013.

ŚWiATŁowsKi A.R.: Koncepcja porozumień karnoprocesowych. PiP 1998, z. 2.

Waltoś S.: „Porozumienia” $w$ polskim procesie karnym de lege lata $i$ de lege ferenda (Próba oceny dopuszczalności). PiP 1992, z. 7.

ZAGRODNIK J.: O pojęciu „wymiaru sprawiedliwości” $w$ kontekście umorzenia postępowania przygotowawczego na wniosek pokrzywdzonego (art. 59a k.k.). „Iustitia” 2015, nr 2.

\section{Orzecznictwo}

Wyrok TK z dnia 1 grudnia 2008 r., P. 54/2007, LexisNexis nr 1968781. OTK-A 2008, nr 10, poz. 171.

Wyrok SA w Łodzi z dnia 21 marca 2013 r., II AKa 31/13, Legalis. 


\section{Inne źródła}

Uzasadnienie rządowego projektu ustawy o zmianie ustawy - Kodeks postępowania karnego oraz niektórych innych ustaw uchwalonej w dniu 11 marca 2016 r. Druk sejmowy nr 207. 